\title{
Mario Wintersteiger
}

\section{Enlightenment from the Orient: The ,Philosophical Esotericism' of the Falasifa Razsvetljenstvo z Vzhoda: ,filozofska ezoterika' falasife}

Abstract: This article deals with the political philosophy of the falasifa, particularly with the specific esotericism of Ibn Rushd (also known as Averroes). One aim of this article is to point out that this tradition was a pre-modern, cautious form of Enlightenment that influenced Western thought via its unorthodox reception by the Latin Averroists. The ,double truth' theory of the latter makes us turn our attention to a writing technique also used by the adherents of falasi$f a$ themselves. Accordingly, the second aim of this article is related to the Platonic style of esoteric political communication. A close reading and interpretation of Ibn Rushd's Decisive Treatise uncovers his position in the conflict between Greek philosophy and Islamic revelation. By referring to passages from the falasifa's works and to insights from Straussian hermeneutics, it is shown that this tradition considered philosophical truth to be politically dangerous, therefore promoting its form of Enlightenment only in an esoteric aspect accessible for the few who were initiated.

Keywords: averroism, enlightenment, esotericism, Ibn Rushd, Leo Strauss, political philosophy, truth

Povžetek: Članek je posvečen politični filozofiji falasife, zlasti specifični ezoteriki Ibn Rušda (znanega tudi kot Averoes). Prvi cilj članka je poudariti, da je bilo to izročilo predmoderna, zadržana oblika razsvetljenstva, ki je vplivala na zahodno misel skozi nepravoverno recepcijo latinskih averoistov. Teorija o ,dvojni resnici', ki so jo zagovarjali slednji, nas vodi k načinu pisanja, h kateremu so se zatekali že privrženci falasife. Od tod je drugi cilj članka povezan s Platonovim načinom ezoterične politične komunikacije. Pozorno branje in interpretacija Ibn Rušdove Odločilne razprave razkriva njegov položaj v sporu med grško filozofijo in islamskim razodetjem. S sklicevanjem na odlomke iz spisov falasife in na uvide hermenevtike Lea Straussa, je pokazano, da je omenjeno izročilo filozofsko resnico imelo za politično nevarno, kar pomeni, da je spodbujalo lastno obliko razsvetljenstva zgolj v ezoteričnem vidiku, dostopnem maloštevilnim posameznikom, ki so bili vanj uvedeni. 
Ključne besede: averoizem, razsvetljenstvo, ezoterika, Ibn Rušd, Leo Strauss, politična filozofija, resnica

\section{Introduction}

Our reflections pursue two aims. The first one is rather obvious and openly declared in the main title of our article. We are giving an account of some sort of Enlightenment that seems to have come from the Orient. One case to be made here is this one: a specific form of esotericism (with roots in the medieval Arab world) contributed to the emergence of modern Western thought. We approach this topic mainly by examining some key features in the works of medieval philosophers like Alfarabi and, especially, Ibn Rushd (or Averroes) - both of them coming from the realm of Islam, although one might plausibly argue that they were not so much »the product of Arab culture, but rather Greek culture (Reilly 2015, 125). Specifically, we focus on the esotericism of their so-called falsafa tradition and its impact on Western »philosophical esotericism« (Melzer 2014, 1).

In order to avoid confusion about the multifaceted term ,esoteric', we have to point out how it is to be understood on the pages of this article. Following Arthur M. Melzer, we define the traditions of ,esotericism' as being marked by the following features: first, by the hidden existence of inner (,esoteric') teachings that are reserved for specifically informed elites; second, by the will to hide those teachings from the masses; third, by the complementary existence of outer (,exoteric') teachings for the multitude. ,Esoteric' (in this sense of the word) is therefore not defined by the character of the content of the secret teaching in question but by its formal structure and the ,secretive mode of communication' involved. (Melzer 2014, 1-2) When thus being defined as a practice, the term ,esotericism" is no longer exclusively reserved to the realm of mysticism and occultism that is usually associated with it but may also contain forms of rationalist philosophy that are communicated secretly or at least indirectly (Melzer 2014, 2-3). This should make clear why we can also use the term for describing specific features of the falsafa tradition without linking it too closely with the world of the occult.

What we call falsafa is a branch of philosophy in the Islamic world of the medieval era, its main characteristic being the heavy reliance of its protagonists (the falasifa) on ancient Greek texts (Kurtoğlu 2007). It is important to note that the meaning of the term falsafa is different from the meaning of hikma, another term used to describe a form of philosophy in the Islamic world. What is called hikma is more ,indigenous' and ,more explicitly Islamic'; falsafa, in contrast, is more ,classical' and heavily indebted to Greek philosophers like Plato and Aristotle. (Groff and Leaman 2007, 162-164) It is a product of an early renaissance within the world of Islam (Molnar 1985, 17), so to say. In an attempt to fulfil the aim of interpreting these currents of thought, our text is an exercise in the intercultural history of ideas and in the hermeneutics of the exoteric and the esoteric in me- 
dieval political philosophy, the terms related to esotericism being used in the broad and formal sense of the definition just given above.

Apart from this there is a second aim, which may not be so obvious at first sight but is at least as important in terms of philosophy and even more important in terms of politics. The guiding theme underlying our short study is one specific feature of the complex relationship between politics and truth. The traditional, Socratic definition of philosophy says that the term signifies the quest for truth (Strauss 1988c, 11). Therefore, anybody interested in the political dimension of knowledge and truth must seriously study the basic "problem of the relation between philosophy and politics« $(1988 \mathrm{~b}, 5)$. But why do we approach the topic of politics and truth in such an unusual way? Why do we write an overview of medieval precursors of the Enlightenment and their esotericism if the common thread of this account is the problem of truth in the context of politics? The reason is that the features we want to highlight here are indeed much easier to discover in these materials, due to some characteristics of the Muslim environment of the main authors we cover. As Strauss (1988b, 18-21) shows, in contrast to the realm of Christianity (where philosophers were integrated but supervised by the Church), the situation of the falasifa in the Islamic world was somewhat more liberal yet more precarious (even before their eventual decline!). ${ }^{1}$ Therefore, the main problems of the relation between politics and (philosophical or religious) truths are more easily demonstrated by referring to examples from the Islamic world; besides that, another advantage of interpreting the tradition stemming from Alfarabi is the fact that it seems to be closer to authentic Platonism than most of Plato's modern interpreters (Kraemer 2009, 141-142); this is not the least advantage when we consider that Plato is a key influence on the hermeneutic tools that we will have to deal with later (Strauss 1988b).

This article, therefore, is a contribution to two separate yet somehow interdependent discourses; accordingly we argue in support of two hypotheses: First, we are going to show that Enlightenment had pre-modern, medieval forerunners with roots in Islamic culture (or more precisely, in the ancient Greek heritage that was preserved there); second, also we are going to provide an interpretation of key passages of this tradition of political philosophy, thereby proving that Ibn Rushd considered the truth of philosophy to be superior to Islamic revelation. In order to do so, we will proceed as follows: Section 2 deals with the school of Latin Averroism and its famous concept of ,double truth', thus opening up our perspective on Ibn Rushd and his followers; Sections 3 and 4 both focus on the falasifa's posi-

The widespread notion that Islamic culture witnessed a »collapse of philosophic inquiry“ (Strauss 1988b, 19) has been met with criticism that pointed out examples of important philosophers even after the so-called "golden age " of Islam (Griffel 2018, 38-47). Therefore, it is necessary to give a more nuanced picture, again distinguishing between the types of philosophy we have already mentioned. While falsafa (that is, philosophy in the Greek sense of the word) declined (at least in the realm of Sunni Islam), the more religious tradition of hikma maintained its importance (Groff and Leaman 2007, 162-164). This helps explaining why the modernist West came to see this "postclassical " transformation of philosophy in the Islamic world as a decline of philosophy itself (Griffel 2018, 45-47). Strauss (1988b, 9-10), in turn, seems to have been referring to the falasifa only when talking about the philosophers' fate. 
tion that (philosophical) truth might be (politically) dangerous and their conclusion that it might be preferable to communicate this truth only esoterically; Section 5 provides an interpretation of Ibn Rushd's Decisive Treatise, using Straussian hermeneutics to uncover his concealed position on the truths of philosophy and religion; Section 6 concludes with reflections on truths and lies in the context of politics and Enlightenment.

\section{The ,double truth' theory as a medieval form of Enlightenment}

First, we have to vindicate our claim that enlightened thought has a medieval (or even older) pedigree. We follow the German philosopher Kurt Flasch (1989) in this regard who provided evidence for the existence of some sort of esoteric Enlightenment movement in the Western Late Middle Ages. One indication of the existence and importance of that school of thought is a famous document which was signed in Paris in the year 1277; the Bishop of the city, Étienne Tempier, published a list of 219 theses that were discussed at the arts faculty of the university at that time, condemning them under threat of excommunication of teachers and students alike. When reading the Bishop's text, a passage from his prologue attracts our special attention; not only did he criticise the teachers of the liberal arts for promoting heresies with the help of books written by so-called pagan authors (that is ancient Greeks and Islamic authors). (Tempier 2007, 180) He also writes the following about the condemned philosophers: "So as not to appear to be asserting what they thus insinuate, however, they conceal their answers in such a way that, while wishing to avoid Scylla, they fall into Charybdis. (180)

What the Bishop is criticising here is a technique of writing called, defensive esotericism' (Melzer 2014, 127) - a practice used by philosophers since ancient times and described in great detail by scholars like Leo Strauss and Arthur M. Melzer: In order to avoid persecution in a precarious environment, sages from all (especially pre-modern) ages were hiding the esoteric core of their arguments under an exoteric surface. This means that they were - in a way - paying lip-service to those in power while presenting their viable but unorthodox philosophical insights ,between the lines'. (Strauss 1988b, 22-37; Melzer 2014, 127-159)

At the time when Bishop Tempier's condemnation was published, religious authorities in Europe seem to have been deeply moved by the fear that certain scholars might teach a , double truth' theory (Griffel 2010, 110-111) that could threaten the monopoly of their monotheist orthodoxy. We quote from the Bishop's document again: »For they say that these things are true according to philosophy but not according to the Catholic faith, as if there were two contrary truths and as if the truth of Sacred Scripture were contradicted by the truth in the sayings of the accursed pagans /.../." (Tempier 2007, 180). Everybody familiar with medieval (political) philosophy will correctly link this position to a school of thought called Latin Averroism - a group of radical Aristotelians influenced by the writings of Ibn 
Rushd (Bianchi 1997, 70-75; Griffel 2010, 110-111) who is considered the last of the falasifa and the most famous commentator of Aristotle. ${ }^{2}$

Let us explain why Ibn Rushd is a key figure when it comes to studying the links between modern Western thought and the Orient. Averroism's, double truth' theory, which could be seen as a kind of medieval precursor of modern Enlightenment's , political esotericism' (Melzer 2014, 235), seems to have been inspired by the esotericism and exotericism of Ibn Rushd (Griffel 2010,111) - we will discuss his positions later. Before that we have to briefly mention that the modified version of an esoteric element of the falsafa tradition, namely Latin Averroism, influenced the school of Padua (including Marsilius) and the rationalism of Italian Renaissance (Molnar 1987, 61-63; Butterworth 1994, passim), possibly including thinkers like Niccolò Machiavelli (Butterworth 1994, 241-245; Strauss 1969, 202-203), one of the founding fathers of modern political thought. Those (or similar) connections have been stated by a couple of scholars, ${ }^{3}$ thus substantiating the view that Enlightenment was influenced by the Orient.

\section{Protecting people from the truth - the esotericism of the falasifa}

Let us now turn to the roots, the esoteric aspects of this school of thought that - following Joel L. Kraemer (2009) - we would like to call the ,Medieval Arabic Enlightenment' of the falsafa tradition. We have to leave aside the question why the falasifa have - in the long run - been much more successful in the Christian West than in the Islamic East. ${ }^{4}$ Instead, we want to turn our attention to those features of the Arabic falsafa tradition that were important for the European reception of esoteric ideas that created a specific form of Enlightenment. As Leo Strauss (1977, passim; 1988b, 14-18) shows in his work on Farabi's Plato and also in his methodological handbook Persecution and the Art of Writing, the falasifa used certain writing techniques to support their aim of creating a political «alliance between philosophers and enlightened princes" $(1977,412)$. Following the Straussian hermeneutics of esotericism, one can say that there had been (at least) two main reasons for their "distinction between the exoteric and the esoteric teaching" $(1988 \mathrm{~b}, 17)$. One of their interests was, of course, self-protection out

2 For a short contextualisation of Ibn Rushd and his status as a philosopher of religion, see Wintersteiger 2018, 95-96, and the sources mentioned there. In the Islamic world at the end of the twelfth century, the falasifa were ,more or less overtaken by theology', although this does not mean the end of Islamic philosophy as such, which was developed further, especially in the realm of Shia Islam (Groff and Leaman 2007, 163-164).

3 For example, one could follow a , neopagan' line of thought starting with Arab esotericism, entering the West via the Averroism of Padua and deepening its influence via the philosophy of the Renaissance, thus entering the modern world and eventually weakening the Christian worldview which was unable to solve the problem of the relationship between faith and reason (Molnar 1987, 61-79).

4 On the impact of Averroism on Western thought, as opposed to the East (which was following the footsteps of Avicenna), see Corbin (1993, 249-251). 
of fear of persecution by authorities, but the second interest was protection of the uninitiated from truths that were considered to be politically dangerous. (1988b, 24-26; 34-36) The latter interest, by the way, is the main feature that distinguished them from the mainstream of their modern European counterparts (Kraemer 2009, 149-150; Strauss 1997, 88-89). As Melzer (2014, 161-203; 235284 ) shows in his Philosophy between the Lines, there is an important difference between old-school ,protective esotericism' (aiming at protecting people from the ,dangerous truths' of esoteric teaching) and modern ,political esotericism" (which aims at actively and deliberately subverting traditional systems). ${ }^{5}$

\title{
4. The parable of the ,drunken mystic' and the ,dangerous truth'
}

We now want to highlight the esoteric method of presenting the truth by discussing some exemplary features from the works of the falasifa. Of course, we have to start with the first of the falasifa and the ",second teacher" after Aristotle" (Mahdi 1987, 207), Alfarabi. We should start with a passage that was described by Butterworth and Pangle $(2001, x)$ as "his most charming passage, the parable of the drunken mystic «. It is taken from Alfarabi's introduction to Plato's Laws and it shall be quoted in full length here:

\begin{abstract}
"/.../ a certain abstemious ascetic was known for his probity, propriety, asceticism and worship, and having become famous for this, he feared the tyrannical sovereign and decided to run away from his city. The sovereign's command went out to search for and arrest him wherever he was found. He could not leave from any of the city's gates and was apprehensive lest he fall into the hands of the sovereign's men. So he went and found clothing worn by vagabonds, put it on, carried a cymbal in his hand and, pretending to be drunk, came early at night out to the gate of the city singing to the accompaniment of that cymbal of his. The gatekeeper said to him, , Who are you? , । am so and so, the ascetic! ‘ he said jokingly. The gatekeeper supposed he was poking fun at him and did not interfere with him. So he saved himself without having lied in what he said.॥ (Alfarabi 2011, 73)
\end{abstract}

This passage has - especially in writings of the Straussian school - been interpreted as an open hint at the art of the Platonic esoteric communication of truth. In this case, the ,dangerous truth' appears in clothes different its own, dressed up in a deceiving way. (Strauss 1988a, 135-137) We will not go into the details of Alfarabi's account of Plato's political philosophy, but we shift the focus back to lbn Rushd. It is pointed out that he writes orthodox religious statements, but it is debateable how sincere he was in doing so $(1997,74-75)$.

In a way, ,political esotericism ' is therefore the opposite of all the other forms (Melzer 2014, 236). The same aspect is also highlighted by Strauss $(1997,88-89)$ when he makes clear that modern Enlightenment is not esoteric in the way the medieval writers had been. 


\section{A truth for political philosophers - the Decisive Treatise of Ibn Rushd}

The Fașl al-maqāl, the Decisive Treatise of Ibn Rushd, was written around 1179. Basically, it is a defence of the Aristotelian philosophy of the falasifa (like Alfarabi) against attacks by orthodox religious thinkers, especially against criticism by Al-Ghazali. (Wintersteiger 2018, 95-96) While not condemning philosophy as such, the latter claimed that the works of the falasifa contained several metaphysical positions that - from the perspective of theology - had to be considered , faithless' (Rudolph 2004, 60). This shows that Ibn Rushd was writing in an increasingly precarious intellectual climate - since a process of ,Dehellenziation of Islam' (Reilly $2015,119)$ was already under way that turned out to be harmful for his form of philosophy. ${ }^{6}$

We will now present some core arguments of the Decisive Treatise of Ibn Rushd which could be interpreted as a key document of esoteric Arabic Enlightenment. ${ }^{7}$ If we look at the text, at first sight we will see Ibn Rushd in his role as a seemingly orthodox Islamic jurist who tries to find out whether philosophy and logics are "permitted, prohibited, or commanded" by the sharia (Averroes 2011, 124-125). He quotes several passages from the Quran - like Sura 59,2 („Consider, you who have sight «) - in order to support his claim that philosophy is obligatory (125). He also claims that a philosophical inquiry has the same goal as Islamic revelation (127). We quote from his Decisive Treatise:

"And [it has become evident] that whoever forbids reflection upon them by anyone suited to reflect upon them /.../ surely bars people from the door through which the Law calls them to cognizance of God - namely, the door of reflection leading to true cognizance of Him. That is extreme ignorance and estrangement from God /.../.» (127)

In passing, Ibn Rushd calls philosophy the ,milk sister' of Islamic Law (140) which is an important detail! According to the custom of milk kinship, milk sisters have a strong connection (resulting in certain privileges), although they are not immediate kin (in biological terms) (Griffel 2010, 207).

So far, we are still on the exoteric surface of the text; it shows all the features needed for ,defensive esotericism' in the sense of Melzer (2014, 127-159): Ibn

6 On the fate of the falasifa and of the philosophy of Ibn Rushd, see Wintersteiger $(2018,95-96$; 99-101) and the sources cited there. According to Reilly (2015), this decline of Hellenic philosophy marks the beginning of what he, referring to Sunni Islam, calls the ,Closing of the Muslim Mind'. This position is a recent variation of the mentioned Western view of the transformation of ,postclassical' Islamic culture, a narrative rooted in modernist values and a specific concept of philosophic thought (Griffel 2018, 35-47). In order not to exceed the framework of this article, we will not repeat what has been said about this discourse in footnote 1 . But we should add that a proper understanding of other civilizations presupposes the awareness that the linear philosophy of history that has come to dominate the West does not necessarily apply to the rest of the world (Leskova 2019, 1057).

7 For some other details of this philosophy of religion, see Wintersteiger (2018). As we will see, this form of Enlightenment, being esoteric in character, is rather complex and nuanced. In its relation towards myth, it does not have a "shallow and superficial form« (Hagedorn 2017, 606). 
Rushd is demonstrating the compatibility of philosophy and religion, citing from the Quran. Symbolically speaking, he is wearing the clothes of an orthodox jurist - but in the same way Alfarabi's, drunken mystic' (Butterworth and Pangle 2001, $\mathrm{x}$ ) was wearing the (exoteric) clothes of a vagabond (Alfarabi 2011, 73). If one reads more deeply into the Decisive Treatise - in search of its esoteric core argument - one will see that Ibn Rushd is going further than just claiming that philosophy is the ,milk sister' of religion. We quote him:

"Since the Law has urged cognizance of God /.../ and of all the things existing through Him by means of demonstration; and it is preferable - or even necessary - that anyone who wants to know God /.../ and all of the existing things by means of demonstration set out first to know the kinds of demonstrations, their conditions, and in what [way] demonstrative syllogistic reasoning differs from dialectical, rhetorical, and sophistical syllogistic reasoning. " (Averroes 2011, 125-126)

At first sight this sounds harmless, maybe even a little bit ,boring' due to the ,many technical terms' - something quite common with the writing technique in question (Strauss 1988b, 24). But what does all this mean for somebody who is reading closely (like a Straussian Platonist) and who is familiar with the aforementioned terms and their meaning in Aristotelian philosophy? Ibn Rushd is referring to Aristotle's categories of logics, in whose works demonstrative reasoning is considered to be superior to dialectical reasoning. So, the passage we have quoted is just a very complicated and obscured way of saying that orthodox theology is a comparatively inferior kind of science because its premises cannot be demonstrated. (Griffel 2010, 163)

Ibn Rushd even goes as far as to creating a social hierarchy related to these categories; for this, another quote:

»/.../ people's natures vary in excellence with respect to assent. Thus, some assent by means of demonstration; some assent by means of dialectical statements in the same way the one adhering to demonstration assents by means of demonstration, there being nothing greater in their natures; and some assent by means of rhetorical statements, just as the one adhering to demonstration assents by means of demonstrative statements. " (Averroes 2011, 128)

If you put this into the framework of Aristotelian logics again, then it means (esoterically) that the teachers of law (or the - we may say - theologians) come only second in the epistemological hierarchy (Wintersteiger 2018, 97-98); therefore, they rank below the pagan philosophers who side with Athens. ${ }^{8}$

Now one might ask: Are we allowed to interpret Ibn Rushd in this way? Should we read him esoterically at all? We are convinced that it is legitimate to do so,

8 Here, the city of Athens has to be understood as a metaphor for Greek philosophy; its counterpart is Jerusalem, the city of the faith of the Bible. On the eternal conflict between those two, see Strauss 1986. 
since the author himself mentions a distinction between exoteric and esoteric - a common indicator according to deep hermeneutics (Weber and Beckstein 2014, 108-111); in formal accordance with a tradition in Islam to distinguish between the exoteric (zahir) surface of revelation and the hidden or esoteric (batin) meanings below this surface, Ibn Rushd develops his own version of philosophical esotericism (Corbin 1993, 245-246). We quote him once again: "This is the reason for the Law being divided into an apparent sense and an inner sense. For the apparent sense is those likenesses coined for those meanings, and the inner sense is those meanings that reveal themselves only to those adept in demonstration." (Averroes 2011, 133) Interpreted in the light of what we have said earlier, this means that only philosophers but not jurists or theologians are able to uncover the esoteric content of the Law (Wintersteiger 2018, 98). The passages we have mentioned may be supposed to do for now. It may be supposed to have become clear that Ibn Rushd, as the last of the falasifa, was an esoteric exponent of what is called, Medieval Arabic Enlightenment' (Kraemer 2009). When it comes to the tension between Athens and Jerusalem (or in this case, we might better say Athens and Mecca) (Brague 1998), he sides with Athens while stating exoterically that there is no conflict between Athens and Mecca at all (although there is one according to the Platonic philosophical tradition) (Strauss 1986)!

\section{Conclusions - ,unpleasant truths' and ,noble lies'}

The pattern thus reconstructed should now be discussed in the light of its impact on Western thought. We must not overlook the difference. The falasifa did not intend to give away their secrets about the Law to the masses - Ibn Rushd even stated that this was forbidden (Averroes 2011, 137). Therefore, this medieval form of Enlightenment is not radical, it is moderate, but it is rationalist nonetheless, and insofar it is a precursor of the modern Enlightenment movement (Strauss 1997, 9-11; 88-89; Kraemer 2009, 148-150). There is continuity in content. But, as Strauss $(1997,89)$ pointed out, the moderns teach exoterically what the elders taught esoterically. Therefore, the moderns' stance toward truth is entirely different. That does not mean that there is no philosophical esotericism left among the protagonists of modern Enlightenment - just think of the Encyclopedists (Melzer 2014, 249-251). But theirs is just - to some degree - a kind of ,defensive esotericism' (fooling the censors), for the most part ,political esotericism' but no ,protective esotericism' any longer (139; 278-279). The Enlightenment of the falasifa, on the other hand, was not for the many, it was for the few; therefore it was politically conservative and made use of ,noble lies' in order not to harm the masses with , unpleasant truths' (Strauss 1988b, 35-36). But it was a kind of Enlightenment and it came from the Orient - where ,philosophical esotericism' was conserved at a time when it was still lost in the West. 


\section{References}

Alfarabi. 2011. Plato's Laws. In: Joshua Parens and Joseph C. Macfarland, eds. Medieval Political Philosophy: A Sourcebook, 72-73. Ithaca: Cornell University Press.

Averroes. 2011. The Decisive Treatise. In: Joshua Parens and Joseph C. Macfarland, eds. Medieval Political Philosophy: A Sourcebook, 123140. Ithaca: Cornell University Press.

Bianchi, Luca. 1997. Der Bischof und die Philosophen: die Pariser Verurteilung vom 7. März 1277. In: Kurt Flasch and Udo Reinhold Jeck, eds. Das Licht der Vernunft: Die Anfänge der Aufklärung im Mittelalter, 70-83. Munich: C. H. Beck.

Brague, Rémi. 1998. Athens, Jerusalem, Mecca: Leo Strauss's ,Muslim ' Understanding of Greek Philosophy. Poetics Today 19, no. 2:235-259.

Butterworth, Charles E. 1994. What is Political Averroism? In: Friedrich Niewöhner and Loris Sturlese, eds. Averroismus im Mittelalter und in der Renaisance, 239-250. Zurich: Spur.

Butterworth, Charles E., and Thomas L. Pangle. 2001. Foreword. In: Alfarabi, Philosophy of Plato and Aristotle, vii-xx. Ithaca: Cornell University Press.

Corbin, Henry. 1993. History of Islamic Philosophy. London: Kegan Paul International.

Flasch, Kurt. 1989. Aufklärung im Mittelalter? Die Verurteilung von 1277. Mainz: Dietrich.

Griffel, Frank. 2010. Kommentar. In: Muhammad Ibn Ahmad Ibn Rushd, Maßgebliche Abhandlung: Fașl al-maqāl, 59-212. Berlin: Verlag der Weltreligionen.

- - - 2018. Den Islam denken: Versuch, eine Religion zu verstehen. Ditzingen: Reclam.

Groff, Peter S., and Oliver Leaman, eds. 2007. Islamic Philosophy A-Z. Edinburgh: Edinburgh University Press.

Hagedorn, Ludger. 2017. Specters of Secularism: Remarks on (the Loss of) Religion and its Implications. Bogoslovni vestnik 77, no. 3/4:601613.

Kraemer, Joel L. 2009. The Medieval Arabic Enlightenment. In: Steven B. Smith, ed. The Cambridge Companion to Leo Strauss, 137-170. New York: Cambridge University Press.

Kurtoğlu, Zerrin. 2007. Eine Kritik der orientalistischen Auffassung der falsafa-Tradition. Polylog: Zeitschrift für interkulturelles Philosophieren, no. 17:39-48.

Leskova, Irina V. 2019. Social Mechanisms of Harmonization of the Relations between Muslim and Christian Culture. Bogoslovni vestnik 79, no. 4:1053-1061.
Mahdi, Muhsin. 1987. Alfarabi: circa 870-950. In: Leo Strauss and Joseph Cropsey, eds. History of Political Philosophy, 206-227. Chicago: The University of Chicago Press.

Melzer, Arthur M. 2014. Philosophy Between the Lines: The Lost History of Esoteric Writing. Chicago: University of Chicago Press.

Molnar, Thomas. 1985. Islam on the Move. The Intercollegiate Review 21, no. 1:17-22.

- - . 1987. The Pagan Temptation. Grand Rapids: William B. Eerdmans Publishing Company.

Reilly, Robert R. 2015. The Closing of the Muslim Mind: How Intellectual Suicide Created the Modern Islamist Crisis. Wilmington: ISI Books.

Rudolph, Ulrich. 2004. Islamische Philosophie: Von den Anfängen bis zur Gegenwart. Munich: C. H. Beck.

Strauss, Leo. 1969. Thoughts on Machiavelli. Seattle and London: University of Washington Press.

- - . 1977. Farabi's Plato. In: Arthur Hyman, ed. Essays in Medieval Jewish and Islamic Philosophy: Studies from the Publications of the American Academy for Jewish Research, 391-427. New York: Ktav Publishing House.

- - . 1986. Jerusalem and Athens: Some Preliminary Reflections. In: Leo Strauss. Studies in Platonic Political Philosophy, 147-173. Chicago: The University of Chicago Press.

- - . 1988a. How Fārābī Read Plato's Laws. In: Leo Strauss. What Is Political Philosophy and Other Studies, 134-154. Chicago: The University of Chicago Press.

- - . 1988b. Persecution and the Art of Writing. Chicago and London: The University of Chicago Press.

- - . 1988c. What Is Political Philosophy? In: Leo Strauss. What is Political Philosophy and Other Studies, 9-55. Chicago and London: The University of Chicago Press.

- - - 1997. Philosophie und Gesetz: Beiträge zum Verständnis Maimunis und seiner Vorläufer. In: Leo Strauss, Gesammelte Schriften, vol. 2, 3-123. Stuttgart: J. B. Metzler.

Tempier, Étienne. 2007. Selections from the Condemnation of 1277. In: Guyla Klima, ed. Medieval Philosophy: Essential Readings with Commentary, 180-189. Carlton: Blackwell Publishing.

Weber, Ralph, and Martin Beckstein. 2014. Politische Ideengeschichte. Interpretationsansätze in der Praxis. Göttingen: Vandenhoeck \& Ruprecht.

Wintersteiger, Mario C. 2018. Averroes (1179), Maßgebliche Abhandlung. In: Michael Kühnlein, ed. Religionsphilosophie und Religionskritik: Ein Handbuch, 95-102. Berlin: Suhrkamp. 